Ireneusz MILEWSKI

(Gdańsk, UG)

\title{
PROBLEMATYKA SPOLECZNA W MOWACH JANA MANDAKUNIEGO
}

Problematyka społeczna była ważnym elementem kaznodziejskiej działalności autorów starochrześcijańskich. Jednym z jej celów była oddolna edukacja społeczeństwa, wiernych, którzy mimo przejścia przez katechumenat i przyjęcia chrztu, nadal mentalnie pozostawali w kręgu dawnej obyczajowości i nie przyjmowali do wiadomości faktu, iż przystapienie do nowej wiary powinno za sobą pociagać rezygnację z pewnych zachowań czy też sposobu dotychczasowego życia, które nie licowały z powagą bycia chrześcijaninem.

Zanim przejdziemy do omawiania zasygnalizowanej w tytule problematyki, kilka słów należałoby poświęcić chrystianizacji Armenii oraz autorowi interesujących nas tu mów, Janowi Mandakuniemu1. Początek chrystianizacji Armenii datuje się na przełom III i IV wieku. Jest on nierozerwalnie związany z działalnością Grzegorza Oświeciciela i nawróconego przez niego króla Armenii, Tyrydatesa ${ }^{2}$. Jak we wszystkich analogicznych przypadkach, chrystianizacja społeczeństwa Armenii szła opornie, o czym świadczyć również może żywotność dawnej obyczajowości w czasach Jana Mandakuniego. Nie do końca jest jednak jasna chronologia jego działalności, a przede wszystkim czas powstania mów, przypisywanych jego autorstwu. Funkcję katolikosa Armenii sprawował on najpewniej w latach $478-490^{3}$.

${ }^{1} \mathrm{Z}$ powodu oczywistej nieznajomości języka ormiańskiego, dla potrzeb powyższego artykułu korzystaliśmy z niemieckiego thumaczenia 25. mów przypisywanych Janowi Mandakuniemu, sporządzonego przez J. Blatza (ze wstępem i komentarzem S. Webera), Reden des armenischen Kirchenvaters Johannes Mandakuni, BKV² 58, München 1927, 29-261. Większość współczesnych badaczy uważa, że ich autorem jest Jan Cac'nut z VII wieku, por. Y. Tabakian, Les homélies du catholicos Hovhan Mandakouni, Antélias 2000; S.J. Voicu, Giovanni Mandakuni (484-498), NDPAC II 2245.

${ }^{2} \mathrm{Na}$ temat chrystianizacji Armenii por. G. Klinge, Armenien, RACh 1 (1950) 683-687; D. Próchniak, Poczatki Kościoła armeńskiego, w: Kościoły Wschodnie, red. J. Drabina = ZNUJ 737, Studia Religiologica 32, Kraków 1999, 33-47; tenże, Od ortodoksji do Kościoła narodowego. Armenia w epoce wczesnochrześcijańskiej (301-726), VoxP 21 (2001) t. 40-41, 49-82. Oprócz powyższych, zob. 5 innych artykułów poświęconych problematyce starożytnej Armenii, opublikowanych w 40-41 tomie „Vox Patrum” z okazji 1700. rocznicy jej chrztu, a także polski przekład opisu chrztu Armenii przez Agathangelosa z odpowiednią bibliografią.

${ }^{3}$ Por. H. Wójtowicz, Jan Mandakuni, ormiański Ojciec Kościoła, SSan 2 (1981) 440-445 
Nasze wywody rozpoczniemy od omówienia krytycznych wypowiedzi Jana Mandakuniego, w których ustosunkowuje się on do nadal żywotnych w jego czasach reliktów praktyk pogańskich. Problem ten w świetle pism autorów chrześcijańskich, działających na terenie Imperium Rzymskiego, był już wielokrotnie omawiany ${ }^{4}$. Niewiele miejsca natomiast poświęcano tej kwestii w odniesieniu do autorów chrześcijańskich, działających poza granicami Imperium. $Z$ tego też chociażby względu warto przeanalizować pod tym kątem spuściznę Jana Mandakuniego. I tak w 25. homilii (numeracja wg ich niemieckiego przekładu) poświęconej zabobonom i zaklęciom, nasz Autor zwraca się przeciw zwyczajowi wytwarzania i noszenia amuletów. Według niego oszustami są ci, którzy je wytwarzają ci zaś, którzy je noszą, sami się oszukują wierząc, iż przedmioty te w czymkolwiek mogą im pomóc ${ }^{5}$. Według Mandakuniego, ludzie noszący amulety zatracają swe dusze, do swego zaś audytorium zwraca się z apelem:

„Poznaliście już prawdziwą wiarę, dlaczego więc nadal tkwicie w pogaństwie przywiązując wagę do tych przedmiotów?. Porzućcie je! [...]. Pokażcie mi choć jednego czarownika, który swymi sztuczkami był w stanie ulżyć własnym cierpieniom"6.

+ przekład z niemieckiego 4. i 24. homilii, tamże, s. 446-453; M. Starowieyski, Stownik wczesnochrześcijańskiego piśmiennictwa Wschodu, Warszawa 1999, 110; Próchniak, Od ortodoksji, s. 72. Inną chronologię działalności Jana Mandakuniego zamieszcza w niemieckiej edycji jego dzieł S. Weber, Einleitung, w: Reden des armenischen Kirchenvaters Johannes Mandakuni, $\mathrm{BKV}^{2}$ 58, 34. $\mathrm{Z}$ zestawionych przez niego danych wynika, iż Jan Mandakuni pełnił funkcje katolikosa Armenii w latach 484/5-498/499; zob. też polski przekład z j. niemieckiego jego 5. homilii przez H. Wójtowicza ze wstępem i bibliografią S. Longosza, VoxP 21 (2001) t. 40-41, 479-488.

${ }^{4}$ Por. m.in. C. Andresen, Altchristliche Kritik am Tanz. Ein Auschnitt aus dem Kampf der alten Kirche gegen das Heidentum, ZKG 72 (1961) 344-376; A.A. Barb, The survival of magic arts, w: The conflict between paganism and Christianity in the fourth century, ed. A. Momigliano, Oxford 1963, 100-125; N. Brox, Magie und Aberglaube an den Anfängen des Christentums, „Trierer Theologische Zeitschrift" 83 (1974) 157-180; M.J. Johnson, Pagan-Christian burial practices of the fourth century: shared tombs?, JECS 5 (1997) 37-59; E.J. Jonkers, Die Konzile und einige Formen alten Volksglaubens im fünften Jahrhunderts, VigCh 22 (1968) 49-53; A. Kehl, Antike Volksfrömmigkeit und das Christentum, w: Kirchengeschichte als Missionsgeschichte, hrsg. von H. Frohnes - U.W. Knor, Bd. 1: Die Alte Kirche, München 1974, 313-341; D. Pasquato, Gli spettacoli in s. Giovanni Crisostomo. Paganesimo et cristianesimo ad Antiochia nel IV secolo, Roma 1970; U. Riedinger, Die Heilige Schrift im Kampfe der griechischen Kirche gegen die Astrologie von Origenes bis Johannes von Damaskos. Studien zur Dogmengeschichte und zur Geschichte der Astrologie, Innsbruck 1957; I. Rochow, Zu den ,, heidnischen” Bräuchen bei der Bevölkerung des Byzantinischen Reiches im 7. Jahrhundert, vor allem auf Grund der Bestimmungen des Trullanum, „Klio” 60 (1978) 483-497; H. Voss, Die Bedeutung des Lichtes in der frühchristlichen privaten und kultischen Totenverehrung, Bremen 1962; M. Whitby, John of Ephesus and the pagans. Pagan survivals in the sixth century, w: Paganism in the later Roman Empire and in Byzantium, ed. M. Salamon, Cracow 1991, 111-131.

${ }^{5}$ Por. Mandakuni, Homilia 25, 1, 44, BKV ${ }^{2}$ 58, 247-269.

${ }^{6}$ Tamże 25, 3, BKV ${ }^{2}$ 58, 248. 
Nawołuje więc, by chrześcijanie, o ile zachodzi taka potrzeba, chodzili do medyków, a nie do szarlatanów, czyniących praktyki magiczne. Zadaniem bowiem lekarza jest leczyć chorego, a wśród stosowanych wówczas zabiegów medycznych, Mandakuni wymienia między innymi: wypalanie ran, amputowanie kończyn, upuszczanie krwi, czy podawanie podawanie różnego rodzaju mikstur uśmierzających ból: takie właśnie praktyki należy stosować, gdy jest się chorym, a nie biegać do czarowników, którzy nie mając wiedzy medycznej preparują jakieś podejrzane mieszanki, chociażby z soli i wegla (?), czerwone amulety (?), wykorzystują perły do uzdrowienia ciał, nakazują nosić u szyi mieszki z wypisanymi na skrawkach pergaminu zaklęciami magicznymi lub rybimi kośćmi oraz drobnymi kośćmi innych zwierząt.

Według Mandakuniego, współcześni mu chrześcijanie zamiast poddać się wypełnianiu woli Bożej, dawnym zwyczajem nadal nawiedzają rzekomych wróżbitów, wyłudzających pieniądze, w nadziei, iż dzięki ich pośrednictwu i ich pomocy, zostanie im wyjawiona przyszłość. Nic bardziej mylnego, by jeden śmiertelnik mógł drugiemu w tej mierze cokolwiek wyjawić. A jeśliby nawet tak było, to według naszego Autora, wiedza taka byłaby w zasadzie tylko utrapieniem dla nieszczęśnika, który dowiedziałby się, jaki czeka go los. Niektórzy jednak, jak stwierdza Mandakuni, chodzą do wróżbitów nie tylko po to, by się dowiedzieć, co zgotował im los, lecz również z tego względu, by się upewnić, chociażby w kwestii zasadności podjęcia trudnej decyzji, na przykład w sprawach finansowych ${ }^{7}$.

Najwięcej okazji do krytyki dawnych obyczajów stwarzały jednak uroczystości pogrzebowe, którym Mandakuni poświęca homilię $23^{8}$. Zwracając się do zrozpaczonych członków rodziny nasz Kaznodzieja w innej homilii apeluje:

„Po śmierci bliskiej ci osoby nie opłakuj go, lecz postrzegaj ten fakt, jako przywołanie do opamiętania się, by za życia czynić dobro i pokutować za grzechy, jakich się dopuściłeś. Zmarłemu już nic nie pomożesz, on odszedł, ale ty sobie nadal możesz pomóc".

Śmierć bliskiego powinna nas skłaniać do refleksji, by stać się lepszym człowiekiem niż dotychczas, pamiętając chociażby i o tym, iż ziemskie bytowanie człowieka szybko przemija. We wspomnianej wyżej homilii Mandakuni stwierdzając, iż nie należy rozpaczać z powodu śmierci bliskiego, zwraca się do swego audytorium z zapytaniem:

„Co jest lepszym dla człowieka, dzień narodzin, czy dzień śmierci? [...]. Człowiek przychodząc na świat, z natury swej posiadając słabą wolę rodzi się do grzechu i do cierpienia oraz zaznaje wszelkich doczesnych trosk"10;

\footnotetext{
${ }^{7}$ Por. Homilia 9, 10, BKV ${ }^{2}$ 58, 128.

${ }^{8}$ Por. Homilia 23, 1-16, BKV ${ }^{2} 58,234-243$.

${ }^{9}$ Homilia 1, 6, $\mathrm{BKV}^{2}$ 58, 53-54.

${ }^{10}$ Homilia 23, 2, $\mathrm{BKV}^{2}$ 58, 235.
} 
wśród nich wymienia także bezdzietność, umierając zaś, uwalnia się od nich. Słuchaczy swego kazania pozostawia z retorycznym pytaniem:

„Co więc jest bardziej radosnym wydarzeniem - narodziny do cierpienia i wszelkich trosk, czy też uwolnienie się od nich poprzez śmierć" ${ }^{\prime 1}$.

Zabrania również okazywania żałoby po zmarłym, tak jak to czynią poganie. Jest to bowiem zabronione tym, którzy zostali ochrzczeni i naznaczeni na swym czole „,pieczęcią krzyża”. Chrześcijanom nie przystoi już targać włosów ani posypywać głowy popiołem, tak jak to czynią poganie na znak przeżywanej żałoby. Zasady bowiem wiary chrześcijan:

„Nie pozwalają obcinać sobie włosów na znak żałoby i rozdrapywać policzków, nie lamentować, nie nosić włosiennicy, kaleczyć czoła, nie posypywać głowy popiołem i głośno zawodzić. Takie zachowanie jest szatańskie i pogańskie, tak u pogan postępują stare baby (tj. płaczki - I. M.)"'12.

A jak w takim razie mają swych zmarłych odprowadzać na miejsce wiecznego spoczynku chrześcijanie? Mandakuni odpowiada z powagą: ciało zmarłego owinięte $w$ całun powinno być odprowadzone przy śpiewie psalmów i innych pieśni wychwalających życie wieczne ${ }^{13}$. Ale przecież nie na każdego chrześcijanina czekało życie wieczne - tego wątku Mandakuni już nie podejmuje.

Dlaczego więc chrześcijanie ośmieszają się, odgrywając na modę pogańską krytykowany przez wielu ceremoniał - pyta Kaznodzieja, a potem stawia swym słuchaczom kolejne pytanie:

„Tak czyniąc, jakim prawem nazywacie siebie chrześcijanami? Dlaczego dawnym zwyczajem idziecie do domu zmarłego, by go tam opłakiwać. Powinniście się wstydzić tego przed żydami i poganami [...], którzy w takich sytuacjach ironicznie pytają: a gdzie podziała się wasza wiara w zmartwychwstanie?"'14.

W odpowiedzi z goryczą stwierdza: chrześcijanie, mimo iż wiara nakazuje im inaczej, w obliczu śmierci bliskiej im osoby zachowują się podobnie jak poganie i żydzi. Mężczyźni na znak przeżywanej żałoby nadal golą swoje głowy, uderzają się w czoło i w piersi, kobiety natomiast głośno lamentując, targają włosy, rozdrapują swe ramiona, policzki i piersi, które ociekając krwią dają widok nieprzyjemny dla innych; kończąc zaś swe wywody w sarkastyczny sposób stwierdza:

„Tak to właśnie zachowują się chrześcijanie, okazując żal po śmierci bliskiej im osoby!"15.

\footnotetext{
${ }^{11}$ Tamże.

${ }^{12}$ Tamże 3, $\mathrm{BKV}^{2}$ 58, 236.

${ }^{13}$ Por. tamże $11, \mathrm{BKV}^{2} 58,240$.

${ }^{14}$ Tamże 4, $\mathrm{BKV}^{2}$ 58, 236.

${ }^{15}$ Tamże 5, BKV² 58, 237.
} 
Według niego, tak postępujących należałoby wyłączyć ze wspólnoty chrześcijan! Na nowo powinni oni trafić pomiędzy katechumenów. Dlaczego? Bo jak stwierdza, ludzie ci wnoszą do Kościoła tylko zwątpienie (m.in. w zmartwychwstanie) oraz niecny pogański zabobon! ${ }^{16}$.

Mandakuni apeluje również do bliżej nieokreślonego duchownego (zapewne wyimaginowanego rozmówcy), kierując do niego napomnienie, by nie dopuszczał do swej owczarni takich, którzy nie są w stanie porzucić dawnych obyczajów, i dodaje:

„Skoro krewni zmarłego poprzez okazywanie w bezbożny sposób żalu po jego stracie przeciwstawiają się Bogu [...], dlaczego ty jeszcze modlisz się za jego dusze"? "?

po czym kolejny raz przechodzi do opisywania scen opłakiwania zmarłych przez ich krewnych ${ }^{18}$.

W innej (15) homilii, poświęconej zbyt lekkomyślnemu i częstemu składaniu przysiag, Mandakuni w ostrych słowach krytykuje ten zwyczaj stwierdzając, iż ludzie są słabi w swych postanowieniach i z tego chociażby powodu nie są w stanie dotrzymać danego przez siebie słowa; z tego też powodu niepotrzebnie narażają się na kłamstwo ${ }^{19}$. Zwyczaj ten jednak jest wszechobecny i trudno go wykorzenić. By nadać większą moc składanej przysiędze tych, którym przysięgaja, wciagają do kościoła, by tam ją złożyć. Co za głupota! - grzmi Mandakuni. Chodzi tu oczywiście o zawieranie umów handlowych. Pyta więc:

„Czy Bóg jest obecny tylko w kościele, a już nie ma go na zewnątrz budynku, nie mówiąc już o rynku, gdzie ludzie załatwiają tego typu interesy?"20.

Wniosek więc z tego, iż wierni czasów Mandakuniego, pozostając mentalnie w okowach dawnych wierzeń i przyzwyczajeń, nadal postrzegali budynek kościoła jako miejsce, w którym mieszka Bóg. Ale nie tylko kupcy zawierający transakcje handlowe przysięgają, czynią to wszyscy, choćby dzieci przy zabawie, walczący wrogowie na wojnie, królowie, a nawet, nad czym szczególnie ubolewa Kaznodzieja, prezbiterzy i biskupi, nie są w stanie dotrzymać danego słowa! $!^{21}$.

Mandakuni wiele gorzkich słów kieruje również pod adresem chrześcijan, którzy z upodobaniem uczęszczają na widowiska teatralne, czemu poświęca

${ }^{16}$ Por. tamże 6, BKV² 58, 237.

${ }^{17}$ Tamże 7, $\mathrm{BKV}^{2} 58,238$.

${ }^{18}$ Por. tamże; zob. także tamże 16, BKV ${ }^{2} 58,242-243$, gdzie Mandakuni kolejny raz apeluje do swego audytorium, by porzucili dawne zwyczaje, by nie dopuszczali do uroczystości pogrzebowych płaczek, by zrezygnowali z całego tego żałosnego przedstawienia.

${ }^{19}$ Por. Homilia 15, 1-17, $\mathrm{BKV}^{2}$ 58, 170-177; zob. też Homilia 9, 10, $\mathrm{BKV}^{2}$ 58, 128.

${ }^{20}$ Homilia 15, 9, $\mathrm{BKV}^{2} 58,173-174$.

${ }^{21}$ Por. tamże 11 i 14, BKV ${ }^{2}$ 58, 174 i 176. 
kolejną (17) specjalną homilię22. Apeluje do nich: „Nie chodźcie na przedstawienia teatralne, bo to zgubny zwyczaj”! Kościół opłakuje tych, którzy swe kroki kierują do teatru i nadstawiają tam swych uszu na „nieczyste głosy”, głupkowate i wyuzdane piosenki, które wnoszą tylko szatańskie myśli do ich serc. Śpiewy te przyrównuje do strzały szatana, wystrzelonej z ukrycia, która będzie tkwić w duszy słuchacza niczym cierń, aż zatruwana przez lata dusza nieodwracalnie się zatraci ${ }^{23}$. A co tak konkretnie niepokoiło Kaznodzieję? Zauważa on mianowicie:

„Tam dziewczęta zachęcane są do nieczystości, małżonkowie zaś do zdrady swych żon [...]. Tam żony uczą się nienawidzić swych mężów, mężowie zaś gardzić swymi żonami. Tam synowie stają się wrogami swych ojców, a niewolnicy swych panów"24.

Kobiety w wystawianych w teatrach frywolnych sztukach przedstawiane sa jako osoby rozpustne, mężczyźni zaś jako lubieżnicy; to szatan miesza się pomiędzy występujących na scenie i kieruje ich poczynaniami ${ }^{25}$. Sama również atmosfera panująca na widowni stwarza okazję do zawierania takich czarcich znajomości: widownia upija się do nieprzytomności winem serwowanym w czasie spektakli, a pod jego wpływem, jak twierdzi Mandakuni, puszczaja wszelkie hamulce. Wspomina on również, iż w teatrze zachęca się nawet do dzieciobójstwa ${ }^{26}$, mając zapewne na myśli spędzanie płodu, jako skutku rozwiązłych zachowań przypadkowych kochanków.

Wypada w tym miejscu postawić pytanie: czy w Armenii w czasach Mandakuniego można mówić o klasycznym greckim teatrze, bardzo popularnym w tym okresie w Bizancjum, gdzie wystawiano prymitywne i frywolne przedstawienia, epatujące seksem ${ }^{27}$. A może Mandakuni bezwiednie powtarza tylko przestrogi autorów chrześcijańskich $\mathrm{z}$ terenów cesarstwa, wygłaszane do wiernych? W jakim zatem kontekście padają interesujące nas tu ostrzeżenia armeńskiego Kaznodziei, gdy i w innych homiliach stwierdzał:

„Ręce nasze są skalane kradzieżą i rozbojem, nasze stopy zaś chodzeniem do teatru" 28 .

${ }^{22}$ Por. Homilia 17, 1-13, BKV² 58, 184-192.

${ }^{23}$ Por. tamże 17, 2-4 i 21, 7, BKV ${ }^{2}$ 58, 185-186 i 217.

${ }^{24}$ Homilia 17, 5, $\mathrm{BKV}^{2}$ 58, 187.

${ }^{25}$ Por. tamże 7, BKV ${ }^{2} 58,188$.

${ }^{26}$ Por. tamże 5, BKV ${ }^{2}$ 58, 187.

${ }^{27}$ Por. S. Longosz, Widowiska teatralne zagrożeniem dla życia rodzinnego wedlug św. Jana Chryzostoma, w: Chrześcijanie a życie publiczne w Cesarstwie Rzymskim III-IV wieku, red. J. Śrutwa, Lublin 1988, 135-198; W. Myszor, Teatr i widowiska w ocenie greckich pisarzy kościelnych. Wprowadzenie i wybór tekstów, w: tamże, s. 123-134.

${ }^{28}$ Por. Homilia 2, 5 i 9, 19, BKV 58, 62 i 133-134. W innej zaś ze swych mów $(9,10)$ stwierdza, że ludzie idąc do teatru ubierają się odświętnie, szczególnie kobiety obwieszają się kosztowno- 
Oceniając powyższe krytyczne opinie Mandakuniego, wypowiedziane pod adresem rzekomo współczesnego mu teatru w Armenii, jego repertuaru i zachowań ludzi odwiedzających to miejsce, odnosi się nieodparte wrażenie, że są to $\mathrm{w}$ większości zapożyczenia $\mathrm{z}$ pism innych autorów starochrześcijańskich, potępiających uczęszczanie wiernych na ówczesne widowiska, chociażby z Homilii do Ewangelii Mateusza, autorstwa św. Jana Chryzostoma ${ }^{29}$, ale zgłębienie tego zagadnienia wymaga osobnego, szczegółowego studium.

Mandakuni wiele miejsca poświęca również krytyce innych negatywnych zachowań społecznych, które, w jego mniemaniu, winny być obce chrześcijanom. W ostrych słowach występuje on między innymi w homilii 7. przeciwko szerzącej się lichwie ${ }^{30}$, dając gdzie indziej także opis miast zapełnionych żebrzącymi ${ }^{31}$. Kieruje przy tym słowa do lichwiarza:

„Nie myśl sobie, że rozdając obficie jałmużnę z zysku zdobytego z lichwy zmywasz swój grzech"32.

W tej mierze późnoantyczni autorzy chrześcijańscy, działający na terenie cesarstwa, byli bardziej elastyczni ${ }^{33}$.

Mandakuni poświęca także osobną homilię szerzącemu się pijaństwu, upatrując w nim przyczynę wielu negatywnych zachowań, w tym też rozpadu życia rodzinnego ${ }^{34}$. O wiele ciekawsza jest natomiast obszerna 19. homilia, skierowana przeciw zjawisku homoseksualizmu żeńskiego i męskiego ${ }^{35}$, której warto tu poświęcić nieco więcej miejsca. Otóż, według Mandakuniego, homoseksualistów należy unikać ,jak złych duchów”, nie można z nimi mieszkać, ani też z nimi jadać, bo nieczystym staje się wszystko, czego „oni dotykają”; wszystko, co zostało dotknięte przez ludzi tejże odmiennej orientacji seksualnej (a wiec zapewne i przypadkowo dotknięci ludzie), uchodzić powinno za „bardziej nieczyste od tego, co w ludzkim mniemaniu uchodzi za najbardziej

ściami i rozpuszczają swe włosy, a takie zachowanie bardziej przystoi ladacznicom niż pobożnym chrześcijankom.

${ }^{29}$ Por. Joannes Chrysostomus, In Matthaeum hom. 37, 6, PG 57, 426; tenże, Homilia contra ludos et theatra, PG 56, 263-270; Longosz, Widowiska teatralne zagrożeniem dla życia rodzinnego wg św. Jana Chryzostoma, s. 161-198 (wybór tekstów + bibliografia).

${ }^{30}$ Por. Mandakuni, Homilia 7, 1-15, BKV ${ }^{2}$ 58, 105-114.

${ }^{31}$ Por. Homilia 8, 6-7, BKV ${ }^{2}$ 58, 117.

${ }^{32}$ Homilia 7, 3, BKV ${ }^{2}$ 58, 107.

${ }^{33}$ Por. chociażby relacje ówczesnych greckich autorów chrześcijańskich: A.T. Georghegan, The attitude towards labour in early Christianity and ancient culture, Wahington 1945, 187-193; R.P. Maloney, Usury in Greek, Roman and Rabbinic thought, „Traditio” 27 (1971) 85-109; I. Milewski, Pieniadz w greckiej literaturze patrystycznej IV wieku (na przykładzie pism Kapadockich Ojców Kościoła i Jana Chryzostoma), Gdańsk 1999, 134-139.

${ }^{34}$ Por. Mandakuni, Homilia 16, 1-10, $\mathrm{BKV}^{2} 58,178-184$; do tej tematyki powraca Mandakuni także w kolejnej ze swych homilii, zob. Homilia 21, 12, BKV² 58, 220.

${ }^{35}$ Por. Homilia 19, 1-18, BKV ${ }^{2}$ 58, 196-205. 
nieczyste" ${ }^{\text {36 }}$, choć nie bardzo wiadomo, co Kaznodzieja miał tu na myśli. Postępowanie homoseksualistów powinno być surowo karane, zasługuje na gromy z jasnego nieba i śmierć w płomieniach. Tak chyba należy rozumieć stwierdzenie Mandakuniego, który konstatuje, że „homoseksualiści [...] zasługują na płomienie" ${ }^{37}$. Za to, co czynia, powinni być surowiej ukarani niż prostytutki, bo choć i one są występne i działają wbrew prawom Bożym, to jednak uprawiany przez nich nierząd mieści się jeszcze w prawach natury. Homoseksualizm natomiast jest gorszy od największych bezeceństw. $Z$ tego też względu, według armeńskiego Kaznodziei, homoseksualiści ściągają na siebie gniew Boży i wrogość innych ludzi; oszczędza on nam, co prawda, bliższych detali z zachowań homoseksualistów, ograniczając się do stwierdzenia, iż ohydne jest już to, że mężczyźni pragną uchodzić za kobiety, a kobiety za mężczyzn, takie zaś zachowania należy tępić wszelkimi sposobami: tacy „odmieńcy” są bardziej nieczyści od „łupieżców ołtarzy” a nawet groboburców ${ }^{38}$. Co więcej, wedle Mandakuniego homoseksualiści są nawet większymi grzesznikami, niż mordercy! Morderca bowiem odbierając życie swej ofierze niszczy tylko jej ciało, ale nie jej duszę, homoseksualista natomiast świadomie zatraca własną duszę. Swoje wywody kończy Mandakuni stwierdzeniem, że homoseksualizm jest nawet większym grzechem, niż pozostawanie w pogaństwie ${ }^{39}$.

Nietrudno zauważyć, że Mandakuni do krytyki reliktów dawnej obyczajowości oraz innych niepokojących go zjawisk społecznych, powracał niemal w każdej ze swych homilii, a można zasadnie przypuszczać, że te, które się dochowały do naszych czasów, to nie jedyne, jakie wygłosił do swych wiernych. Odnosi się też wrażenie, jakoby słowa Kaznodziei adresowane były zaledwie do drugiego lub trzeciego pokolenia chrześcijan, w których nadal jeszcze silnie pokutowało przywiązanie do dawnej obyczajowości. Jeśli więc uznalibyśmy tę ostatnią uwagę za zasadną, wówczas być może należałoby powrócić do upowszechnionej we wcześniejszych badaniach chronologii powstania homilii przypisywanych Janowi Mandakuniemu, a mianowicie na 1. poł. V wieku ${ }^{40}$.

\section{THE SOCIAL MATTERS IN THE PREACHING OF JOHN MANDAKUNI}

\section{(Summary)}

Social problems were important elements in the preaching of the ancient Christian writers. Interesting, yet little-known examples of such activities are

\footnotetext{
${ }^{36}$ Tamże 5, BKV² 58, 199.

${ }^{37}$ Tamże 4, BKV² 58, 198.

${ }^{38}$ Por. tamże 9, $\mathrm{BKV}^{2} 58,200$.

${ }^{39}$ Por. tamże 10, BKV ${ }^{2}$ 58, 200-201.

${ }^{40}$ Odmienne stanowisko w tym względzie prezentuje M. Starowieyski (por. SWPW 110), który nie wyklucza (nie uzasadniając jednak bliżej swego przypuszczenia), iż powstanie interesujących nas tu homilii, przypisywanych Janowi Mandakuniemu, należałoby datować dopiero na VIII wiek.
} 
the speeches of John Mandakuni, one of the Fathers of the Armenian Church. In 25 homilies analysed by me, John Mandakuni, besides making references to the social matters, also strives to fight the pagan customs that were adopted by Christians into their everyday lives. According to his account, and the correctness of Mandakuni finding is confirmed by other contemporary Christian preachers, these habitual pagan practices were particularly deeply rooted in Christian wedding festivities and funerals. 
